\title{
SPACES OF PLAY \\ The Spatial Dimensions of Underground Club Culture and Locating the Subjunctive
}

-

\author{
Alice O'Grady \\ UNIVERSITY OF LEEDS (UK)
}

\begin{abstract}
This article examines the interrelated concepts of space, play and performativity in relation to the underground club scene in the UK. Grounded in the discipline of performance studies, this article uses the lens of play to identify how the spatial characteristics of underground dance culture provide a fertile terrain for performative acts of collectivity and expression. Resonating with previous EDMC scholarship that invokes concepts of liminality and the social dimensions of "spontaneous communitas", the physical and psychical dimensions of play will be considered. Applying Turner's work on subjunctivity (1982) and Jill Dolan's concept of "utopian performatives" (2005) in relation to the psytrance scene, the article positions the underground party as a playful arena, a spatial construct that offers a context for moments of individual and collective transformation that are expressed and experienced performatively.
\end{abstract}

KEYWORDS: psytrance, play, performance, playful arena, subjunctivity, liminality, festival, protest, transformation

Alice O'Grady is Senior Lecturer in Applied Theatre at the School of Performance and Cultural Industries, University of Leeds, UK. Her research deals with interactive performance and play theory, particularly within underground club culture and contemporary music festivals. Much of her work is site-sensitive and examines the relationship between space, context and identity. Email: a.ogrady@leeds.ac.uk

Dancecult: Journal of Electronic Dance Music Culture 4(1): 86-106 ISSN 1947-5403 @2012 Dancecult http://dj.dancecult.net

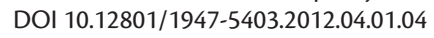

dsincecult 


\section{INTRODUCTION}

THIS ARTICLE examines the interrelated concepts of space, play and performativity in relation to the underground club scene in the UK. ${ }^{1}$ Although its application is not confined to one musical genre only, this research has developed with particular interest in the performative aspects of psytrance, an EDMC that has at its roots a commitment to countercultural ideology and spiritual expansion (Partridge 2006; St John 2004, 2009a, 2009b, 2010). The work under discussion here represents one aspect of extended practice-based research on interactivity and underground club culture with my performance company ...floorSpace....2 This work was conducted at Shamania, one of the UK's alternative psytrance festivals, during the period between 2006 and 2009 (see O'Grady 2009). This research involved devising a series of bespoke performances that were participatory in nature and that were designed to augment the innate playfulness of the festival space and its inhabitants by engaging them in interactive performance in and around the dance floors and the festival's open spaces. In parallel to this practice, participant-observation took place at a range of club nights within the north of England. These events were characterised predominantly by psytrance and a crossgenre blend of acid techno, hard techno, hard trance and minimal techno. They included well-established nights such as Riff Raff, Cabbage, Planet Zogg and Sunrise, all of which have been running for more than 10 years. The demographic of these events largely reflects that longevity, with many attendees being into their $40 \mathrm{~s}$ and beyond. Many of these older psytrancers have families, careers and significant professional responsibilities but remain committed to the scene and its overarching ethic of mindfulness and creative communication. The DJs, artists and crews driving this scene feed also into the alternative festival circuit with considerable cross-pollination of aesthetic tastes and ideology between events.

The series of bespoke performances created between 2006 and 2009 are not the focus of the discussion here, although my argument is informed by those experiences and my participation in the events listed above. ${ }^{3}$ Rather, it is the (sub)cultural formation and spatial dimensions of the context in which these occurrences took place that are under consideration. Grounded in the discipline of performance studies, this article uses the lens of play to identify how the spatial characteristics of underground dance culture provide a fertile terrain for performative acts of collectivity and expression. Resonating with previous EDMC scholarship that invokes concepts of liminality (Gauthier 2004, 2005; Gerard 2004; Malbon 1999; St John 2009a, 2009b, 2010; Sylvan 2005) and the social dimensions of "spontaneous communitas" (Olaveson 2004; Rill 2006; Tramacchi 2000), the physical and psychical dimensions of play as it manifests in the underground party scene will be considered. Underground spaces will be positioned as sites that offer a context for individual and collective play that is expressed performatively. As an important marker of identity (Bourdieu 1979) and as an active player in the formation of expressive identities (Hetherington 1998), play space and how it is constructed, shaped and aestheticised for the purposes of the party will offer another perspective on the conceptual relevance of underground performativity. 
The latent performativity of club culture has been a topic of scholarly debate since the emergence of rave culture in the late 1980s. Buckland (2002) addresses the role club culture plays in the construction and expression of identity, particularly gender, and situates involvement in the scene as a form of queer world-making. Jackson (2004) explores the social and sensual knowledge that arises out of clubbing. He examines the affective register of participation in a variety of different scenes and suggests ways in which these experiences spill over into the everyday to influence the structure of people's lives even after the party is over. Malbon (1999) looks at the expressive nature of club culture, the bodily and emotional experiences of going clubbing and how those experiences are produced. He is explicit in his reading of clubbing as a form of play. Rooted in social geography and anthropology, he provides a deft summary of the various cultural definitions of play and how these map onto the club experience as well as providing insight into the experience of "flow" in this context (see Malbon 1999: 136-49).

My own perspective owes much to this rich and comprehensive scholarship but goes slightly further in making a direct link between participation in the underground scene and the spatial dimensions of play as a mode of behaviour and as an attitudinal stance. Examining how socio-cultural attitudes to play are formulated and how they shift across generations and geographies (both political and environmental) gives insight into how dance culture (as a form of play) is embraced, sanctioned or marginalised by various groups of people, institutions or organisations who seek to minimise its potency or harness its potential. The cultural positioning of play (rather than the state of "flow" that might arise from it) and the ambivalence that often surrounds it, particularly when authorities seek to control or regulate it, is of concern here. To that end, my intention is to use the frame of play as a way of "reading" the underground dance experience but also to draw attention to the notion that playing in the underground has deep socio-cultural implications. It provides a space for and a potential pathway towards a way of "being in the world" that resists fixity, embraces possibilities and offers the promise of mutuality.

The personal, social and educational benefits of engaging in play are well documented (Gardner 1982; Piaget 1951; Sutton-Smith 1997; Vygotsky 1978; Winnicott 1971). The instrumental value of play has become such an accepted paradigm in contemporary culture that the point hardly needs to be reiterated here. If we accept that the rave might be conceived as an adult playground, a space that gives license to certain types of playful behaviour and one which offers fun, excitement, social engagement and interaction, then we can assume that those participating in it must benefit from it in some way, however problematic that might be to demonstrate in concrete terms. Rather than trying to measure the "success" of play in this context, I intend to offer an analysis of what I call the "playful arena of the underground" (O'Grady 2009). Without forgetting the importance of fun and sheer exuberance that infuses clubbing, I will examine how play can be deployed to fulfil functionalist imperatives. Using Jill Dolan's concept of “utopian performatives", I will trace how theatrical notions of efficacy provide a framework for understanding "the fleeting intimations of a better world" (2005: 2) that run through the multi-perspectival narratives of underground dance culture and rave. 
Play as a modus operandi has been used by artists and activists for decades, particularly since the "performative turn" of the 1960s (Fischer-Lichte 2008), and has likewise been mobilised by various underground collectives and sound systems for creative, aesthetic and political ends. The playful realm of the Temporary Autonomous Zone, or TAZ (Bey 2003), provides a space for transgressive radicalism. From this, there emerges a performative repertoire that is perhaps best characterised by the direct action movement in the UK of the early 1990s and has since developed into a recognised underground aesthetic that is global in its distribution. It is the transformative quality of play and how that has become embedded in the aesthetics of the underground that is of particular interest to performance practitioners like myself who are creating work that has co-presence, social engagement and embodied participation as its core ethic.

When dealing with the possibility of performative transformation, one cannot bypass the work of Victor Turner, and in that respect this article follows the same trajectory. The explicit focus on play here orientates his work in a slightly different way. My attention is on his notion of subjunctivity, the "what if ?" of the liminal space that corresponds closely to the experiments of theatre director and playwright Bertolt Brecht (see Mumford 2009), the Brazilian performance practitioner Augusto Boal (see Cohen-Cruz and Shutzman 2006) and other artists who have sought to use the fictive realm of the playworld as a means of questioning how the world might be conceived differently. By dwelling in the realm of the subjunctive, I will argue that play and performance in the underground provide a potential route towards creativity and social critique that can be individually experienced and collectively expressed, in turn lending it a potency that extends beyond the physical time and space of the party.

\section{The Playful Arena of the Underground}

Play is very hard to pin down or define. It is a mood, an activity, an eruption of liberty; sometimes it is rule-bound, sometimes very free. It is pervasive. It is something everyone does as well as watch others engage in - either formally ... or casually. ... Play can subvert the powers-that-be, as in parody or carnival, or it can be cruel, absolute power (Schechner 2006: 79).

OFTEN COUCHED in positive terms by educationalists, psychologists and sociologists, the function of play is usually linked to learning, development and socialisation (Sutton-Smith 1999 ) and as such is "useful" to us in a number of contexts. Play infiltrates and infuses our lives to such an extent that it becomes implicated in all spheres of human activity, from the cultural to the spiritual, from the sacred to the profane (Huizinga 1949). As such, it is pertinent to the analysis of EDMCs, particularly those that have the ethos of spirituality, transformation and transcendence embedded within their aesthetic.

As a device of the imagination, the play mood affords the pursuit of Turnerian subjunctivity (1982). Play revels in the "what if ?", and by operating in this rhetorical mode it remains improvisatory, malleable and open to the processes of imagination. As well as 
being inherently slippery as a term, play is also ambivalent in its application. Play can be frivolous and useful, trivial and meaningful, progressive and regressive simultaneously. The same ambivalence is inherent in underground club culture. Playing and raving can function simultaneously as escape from daily life and as confrontation of reality. Play in the context of the underground party can often be light, theatrical, spectacular, fun and socially engaging. At the same time it can be dark, subversive, disturbing, disorientating and potentially fatal, particularly in relation to the risks associated with drug experimentation, sleep deprivation, heat exhaustion and so on. In this instance I have drawn polar extremes of light and dark, positive and negative characteristics that sit in apparent opposition to each other, but play does not sit comfortably in neat binaries such as these. Like the "joker in the neuroanthropological pack" (Turner 1983: 233), play slides between categories and has no difficulty adopting dual positions. For example, play can be both fun and dangerous simultaneously. Indeed, the fun is often in the danger. Within the underground dance scene, it could be argued, play is ultimately characterised by the co-presence and intertwining of light and dark. Play recognises and revels in the inbetweenness of things.

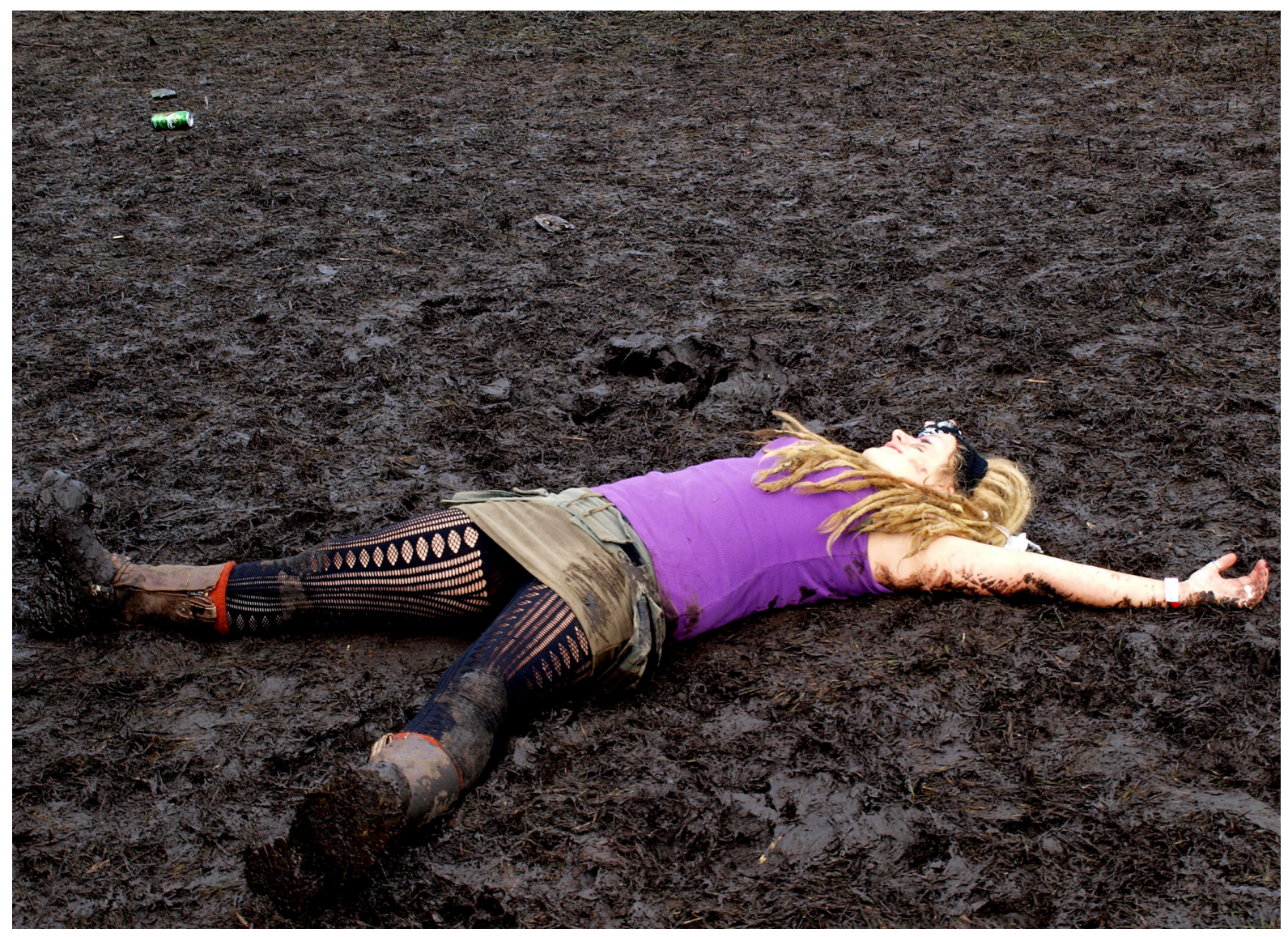

Figure 1. Festivalgoer in mUd at Shamania 2008.

PHOTO : IAN M. PALMER, MADSNAPPER <HTTP://WWW.MADSNAPPERPHOTOS.COM>. 


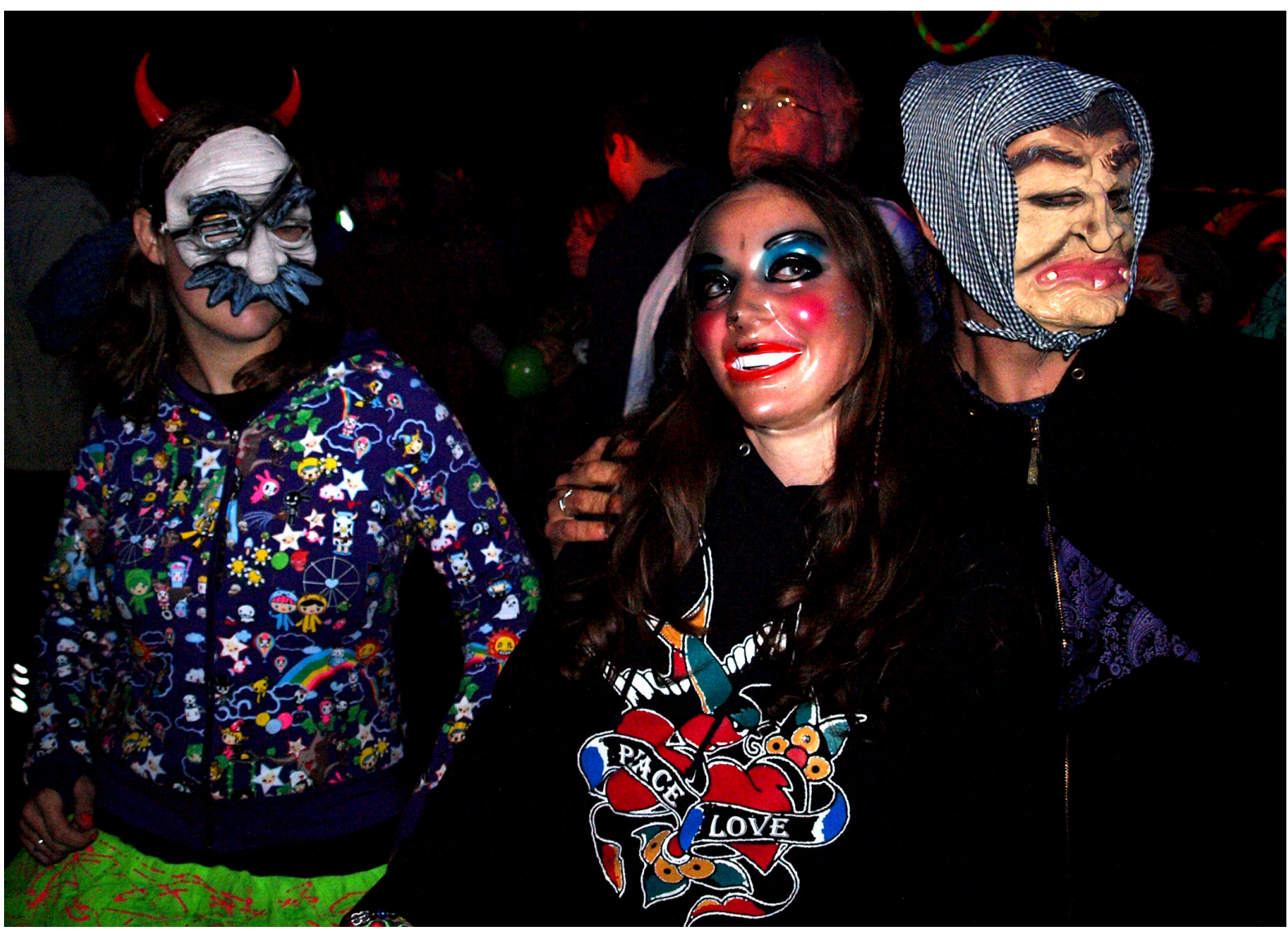

Figure 2. Masked festivalgoers at Shamania 2008. Photo: Ian M. Palmer.

Whatever form play takes, my premise is that the underground club space functions, in part, as an adult playground where people are afforded the opportunity to engage in free, voluntary activity in spaces that are symbolically separated from the world of the everyday and marked out as "special". In this subterranean environment, conventional codes of behaviour are more relaxed, binaries begin to collapse (for example, divisions between day and night, spectator and spectacle, reality and illusion) and participants are thus able to experiment with ideas, identities and (re)constructions of self in a characteristically supportive atmosphere (Buckland 2002: 108). The "nowhere/nowhen" space of the underground party (Reynolds 1999: 55) is a curiously floating context that is not necessarily rooted to the precise geographical location in which it takes place but can be inhabited as a place of transience and impermanence that, in turn, imbues it with a certain looseness and freedom. With such a strong visual identity, the psytrance party looks familiar wherever it finds its home. However, unlike Augé's concept of non-lieu where any emotional engagement with place is lost and individual identity swallowed up (1995: 48), the "nowhere/nowhen" space of the underground is often charged with emotion and memory. It can provoke intimate connections with place that are predicated more on the bodily co-presence of participants than they are on localised specificity. Here, participants are able to imagine alternative ways 
of being and doing and are able to develop the means by which those alternatives may be expressed and played out on the dance floor, in the warehouse or within the parameters of the festival. Play provides the vehicle for this expression and gives rise to performative behaviour and performed outcomes that constitute a type of underground repertoire that is highly visual, exuberant and draws heavily on interdisciplinary modes such as community arts, installation, processional performance and carnival.

Commitment to play and performance can be seen most visibly at events such as Glade, an underground electronic dance music festival that is held annually in the UK. The 2011 event that I attended, described as "a playground for grown up kids" (Moore 2011), offered a number of opportunities for gaming, theatricality and participatory performance that augmented the playfulness of the festival space and encouraged people to experience the party through the mode of play. Fancy dress was encouraged and a number of stalls were set up to facilitate this. There was walkabout performance, a micro-rave on a bicycle, handmade art vehicles, a mobile hula hoop stall and zorbing. ${ }^{4}$ One of the most popular attractions was the Dance Off Saloon where contestants competed against each other in a boxing ring in various states of fancy dress whilst the compere whipped up the crowd and generally added to the atmosphere of comic mayhem. ${ }^{5}$ Another opportunity for play was the Rabbit Hole, an Alice in Wonderland installation where participants (if they were lucky enough to discover it) were made to answer a riddle at the entrance and given a carrot in return. At this point they had to crawl on hands and knees through a tunnel lit by fairy lights before emerging into a secret underground club complete with an under-lit dance floor, DJ booths, flamboyantly-dressed characters and a party in full swing but out of sight of the main festival. The attention paid to play and performance in this context undoubtedly plays a big part in the advertising of festival events as crews compete to secure ticket sales in an increasingly saturated market. However, there is significant bleed between relatively large-scale EDM events such as Glade and the smaller-scale underground party scene. Participatory performance and play has become a recognisable feature of both, not only as part of the scheduled programme but also as a personal repertoire for individuals and groups that shape their own play as the party unfolds.

In order to theorise more broadly from the specific examples given above, it is useful to think of these activities as being arranged along the continuum of play as suggested by Roger Caillois (2001: 13). In his model, the way people play can be situated between two opposite poles. At one extreme is paidia, a type of uncontrolled fantasy where free improvisation, turbulence, diversion and carefree gaiety are dominant. At the other end of the spectrum is ludus, characterised by more rule-bound activity that requires greater effort, patience, skill or ingenuity. Ludus sits in contrast to the anarchic spirit of paidia. Whilst one might assume that the playful arena of the underground subscribes more to the ethos of paidia, it is interesting to note that both categories are well represented and that playful activity associated with circus performance is a notable feature of many psytrance parties. In this context formal game-playing that has a spectacular or theatrical edge and requires some measure of skill and mastery from the player may include juggling, poi twirling, fire staff, hoop play, aerial work, 


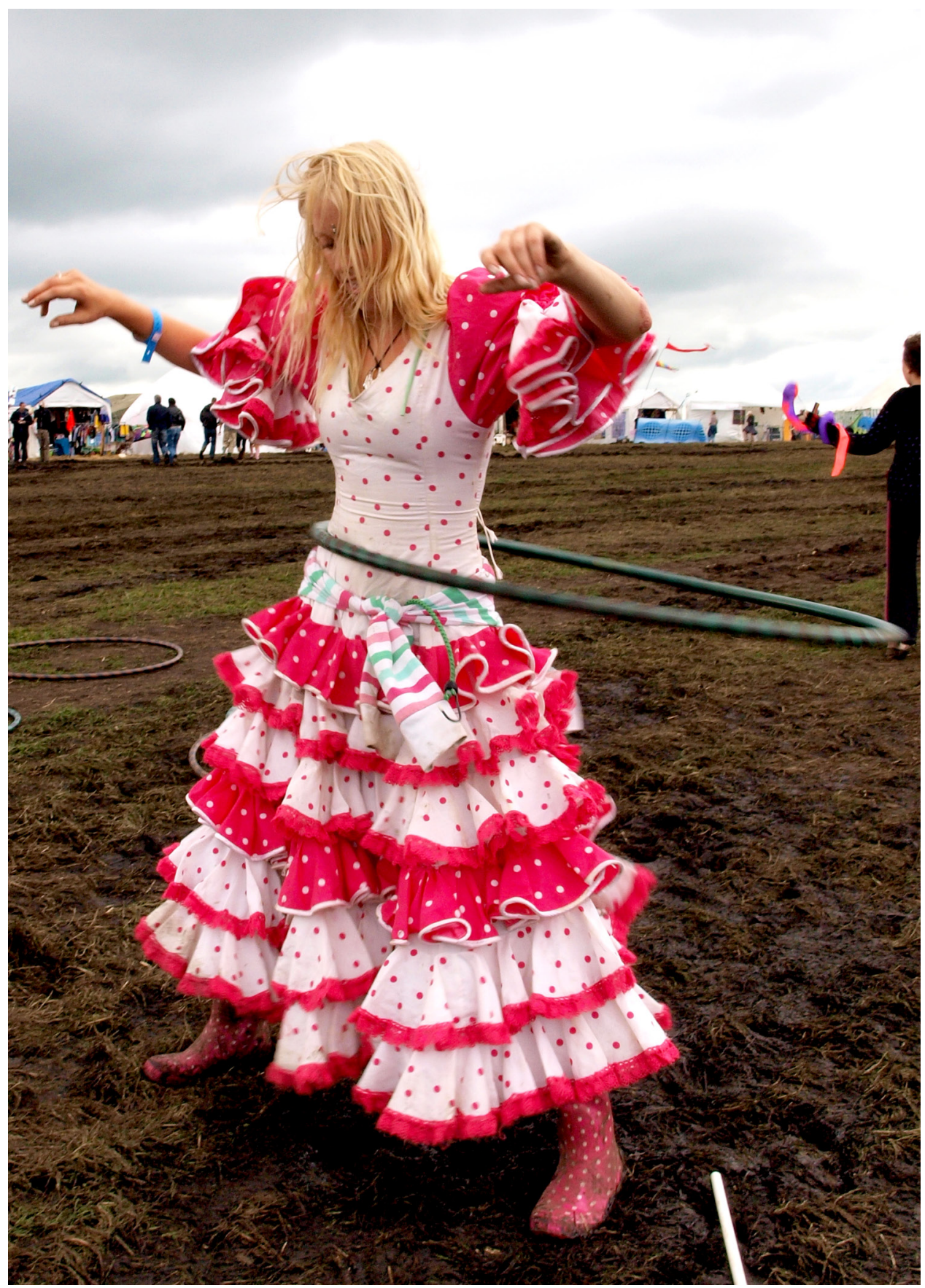

Figure 3. Hoop play at Shamania 2008. Photo: Ian M. Palmer.

walkabout performance or finely-rehearsed stage shows that all contribute to the highly visual terrain of the party. Instances of play associated with improvisation, looseness, and freewheeling include more inclusive forms of social and ecstatic dancing, trance, the play of multiple social interactions and Bey's notion of "radical conviviality" (1994). Other forms of play more associated with the theatrical world can be seen in participants' use of 
playful costuming, disguise and parody. On the psytrance scene in particular, fairies, angels, aliens, insects and other fantastical or other-worldly forms of dress are all fairly common and represent forms of display often associated with carnivalesque inversion and grotesque realism (Bakhtin 1998). Less visible but still noteworthy are the instances of what might be classed as "deep play" (or even dark play), where the stakes of the game are so high that one might question the rationale for participating in the first place (Geertz 1973). In the underground, this might include experimentation and risk-taking along and across the edges of experience involving the use of psychedelics and other substances to achieve a sense of transportation and reconfiguring of self. It might also include playful experiments with sex, sexuality, gender and identity. To a certain extent, the space of the party offers a play zone that protects its players from the outside world. By adopting a party persona, individuals can achieve a degree of distance from self that affords them certain freedoms. The seemingly inert phrase, "I'm only playing", is in fact invested with great potency and sanctions behaviour that would not otherwise be acceptable. Whilst this stance can have positive outcomes in that it loosens the strictures that govern daily convention, it becomes more problematic when considered as a form of power play between individuals or groups, particularly if those relations are governed by distinctions of class, gender or race. Whilst it is certainly possible to identify recurring instances of playful behaviour that span the spectrum of paidia to ludus and to detail moments of risky play that take on an altogether darker edge, what is more interesting to consider are the topological characteristics of the playing space and how that formulation of space is constructed, maintained and utilised by its occupants.

In a similar way to the theatre space, the temple, the courtroom and other spaces imbued with the symbolic registers of play and ritual, the playful arena of the underground party is framed, hedged or separated from the world of the everyday in order to keep it "special". The performance practitioner and director of interactive theatre Garry Izzo uses the Greek word "temenos" to denote a sense of the sacred circle that wraps play and its players in order to keep it safe and separate from the routine world. He suggests this sacred circle can exist both in the physical world as well as in the mind of the players (1997: 9) lending it a psychical dimension as well as a material one. In the underground context, the sacred circle may manifest as a physical building but might also be strengthened by the physical positioning of the event (with parties often occurring in out-of-the-way places, disused or appropriated buildings or rural locations). This might also be achieved by temporal frameworks or through the use of devices such as tickets, wristbands, perimeter fences and security personnel (in the case of many festivals) to identify "insiders" and to exclude or keep at bay the "outside" or "outsiders" for the duration of play. Needless to say, these practices of protection that maintain the playing space and keep it safe from interference can also involve the active exclusion of certain people or groups. This aspect is much heightened in the free party scene where issues of legality and license mean that only those "in the know" can access the space at all.

Regardless of what threshold devices are in place, as a floating space that exists in the minds and memories of the participants long after the event has finished, the playful 
arena is porous. What is felt and experienced within the event cannot be "unfelt" and thus transforms its participants as they take their experience with them back into their daily lives. This notion of porosity is echoed by St John who suggests that, as a lived utopia, the vibe of the underground dance space always holds the potential to exceed its borders (2009a: 121). The sacred circle may be bounded by time (the length of the party) and space (its physical location), but what is experienced within its parameters bleeds into quotidian existence. As spaces of play, experimentation, and imagination playful arenas provide an opportunity to consider the "what if ?" of existence. Underground events therefore can be conceived as "festal interzones" or "experimental theatres of change" (St John 2009a: 147) where processes of transformation, however small, may be put into train using play as its engine.

\section{Underground Play, Efficacy and Utopian Performatives}

LIKE THE CONCEPT OF PLAY, the notion of performativity is often associated with function, efficacy and transformation (see Fischer-Lichte 2008). As play in the underground context gives rise to opportunities for performative behaviour and, indeed, more structured devised acts of performance, the two concepts are intimately intertwined. It has previously been established that participation in clubbing can be seen as a performative act (Buckland 2002; Malbon 1999; Muñoz 2006; O'Grady 2009). However, the spatial, structural and attitudinal qualities of play that help to achieve this have largely been unexplored. The modelling of the playful arena attempts to address this and allows us to draw parallels across the distinct but complementary territories of performance studies and EDMC scholarship.

In the Austinian sense of the word, performative utterances perform actions; they bring forth an altered social reality (Austin 1963). Put simply, speech acts and bodily acts of performativity change things. The extent of this or its potential impact is clearly much harder to pin down. Clubbing and playing are two experiential, embodied modes of activity that are open to deeply personal intersubjectivities and are inherently ephemeral and resistant to capture, making any attempt to measure efficacy or transformation fraught with difficulty. Despite this, it is possible to identify structural similarities in the way the two activities are framed and function in temporary communities that prioritise co-presence, participation and radical conviviality that, in turn, allow for the possibility of transformation to occur. Perhaps the most well-documented example of this that has an explicit link to political transformation is the series of events that took place during the free party/protest movement of the 1990s in the UK. Here, activists sought to combine their desire to dance with an ideology to win back space in the form of large-scale road protests and ecological demonstrations, for example those organised by Reclaim the Streets, Rinky Dink and the Exodus Collective. ${ }^{6}$ The latent performativity of these protests took the form of "ephemeral festivals of resistance" (McKay 1998: 139), were expressed as "participatory ritual theatre" (Jordan 1998: 141) and were broadcast widely on national television. ${ }^{7}$ Activists in this instance deployed music, dance and visual art as well as physical acts of endurance and hardship to help articulate explicit political aims. Occupying contested spaces that sat literally between existence and destruction (in the case of Claremont Road in London 
during the 1994 protests against the development of the M11 link road), protestors created a liminal aesthetics that used sculpture, banners, visual art, puppets, stilt walkers and bassheavy techno music to underscore its point. Whilst these moments of performative resistance did not ultimately achieve comprehensive political U-turns, occupying a radical space of play did allow protestors, and the rest of the world seeing scenes unfold on television, to enact and embody the question "what if ?", albeit for a limited period of time.

Whilst the example above sought to achieve political transformation on a relatively large scale, the performance academic Jill Dolan's concept of "utopian performatives" is particularly useful here in helping to identify the smaller instances of personal shift that might be experienced through underground play. Adopting her perspective, the utopian narratives and the quest for PLUR that continue to infuse the underground can be understood as ongoing processes, modes of behaviour, rather than a singular project that is ultimately doomed to failure. ${ }^{8}$ Dolan argues that live performance provides a place where people come together to share experiences of meaning making and imagination that can grasp towards the realisation of a better world (2005: 2). With an investment of energy in a better future, audiences feel allied with each other and connected to a wider public where social discourse articulates the possible rather than dwelling on perceived obstacles. In her modelling, "utopian performatives" are small but profound moments where performance calls the attention of the audience and lifts everyone slightly above the present. They provide an insight into what our lives would be like if every moment was "as emotionally voluminous, generous, aesthetically striking, and intersubjectively intense" (Dolan 2005: 5), sensations that clearly resonate with experiences on the dance floor. These theatrical moments are described as being akin to "a fleeting epiphany" (Dolan 2005: 5). They can be likened to that moment of optimal experience in the rave that St John calls "the vibe" (2009a: 94) and which comes close to Turner's concept of "spontaneous communitas", a state that offers a "direct, immediate and total confrontation of human identities" (1982: 47).

Achieving "the vibe" and experiencing the "flash of lucid mutual understanding" (Turner 1982: 48) is one of the key components of what I call "clubbing communitas" (O'Grady 2009) or what others have called "psychedelic communitas" (Tramacchi 2001: 184) or "hallucinatory communitas" (Schmidt 2009: 138). Dolan herself uses the term "communitas" to describe the moment at which "spectators' individuality becomes finely attuned to those around them, and a cohesive if fleeting feeling of belonging to the group bathes the audience" (2005: 11), another sentiment that finds its parallel in testimonies from the underground as detailed by Malbon (1999). The strong sense of belonging and identification with others is facilitated by the presence of the sacred circle of the playful arena where play, ritual and imagination collide and can be allowed to flourish for a period of time. The space allows participants to try out and embody alternative ways of being in the world. It allows temporary communities to come together to envisage and practice versions of a better world. In this sense, the utopian enterprise is an action or a process rather than a fixed point in space and time that is either reached or not. As Dolan points out, although many commentators conceive utopia as a destination, performance (and, I 
would argue, play) allows us to see utopia as a process of spending time (2005: 13) that integrates social, political and aesthetic concerns. The playful arena of the club space is not merely a protected environment where what might be perceived as sheer childishness and latent hedonism reign for a pre-determined length of time (although, conversely, it can be that too and is not without its own rewards). With this in mind the underground party can be repositioned as a space where spending time on playful pursuits may be read as the exploration of potentiality and possibility that then, due to its porosity, infiltrates and influences the shape of daily life.

\section{The Liminal Paradigm, Subjunctivity and Rehearsal}

WHILST acknowledging the limitations of what has become known as "the liminal norm" (McKenzie 2001:49-53) and being wary of applying an unmodified application of Turnerian theory (St John 2010: 225), the concept is still useful in this context. The inbetweenness it represents is exemplified by the spatial-temporal characteristics of the underground party as well as the (sub)cultural position it adopts, resting as it does at times in the grey margins of legality, license and sometimes "black market" economies. As Turner states:

I sometimes talk about the liminal phase being dominantly in the "subjunctive mood" of culture, the mood of maybe, might be, as if, hypothesis, fantasy, conjecture, desiredepending on which of the trinity of cognition, affect and connation is situationally dominant. .. Liminality can perhaps be described as a fructile chaos, a storehouse of possibilities, not a random assemblage but a striving after new forms and structures (Turner 1986: 42).

Here, Turner talks of the liminal phase as being in the subjunctive mood of culture. It operates as a separate slice of existence that allows individuals to inhabit the realm of "what might be" for a limited period of time. The underground party can indeed be understood in this way, as it offers a temporary space of fun, fantasy and escape that in itself is restorative, energising and palliative. However, in my formulation rave not only revels in subjunctivity as a parallel to, or flight from, dominant culture. Rather, it provides a type of training ground, or rehearsal space, for developing a particular way of thinking about the culture and our place within it. Like the fictive world of the stage or the realm of fantasy associated with child's play, the underground space operates in a permanent state of maybe and thus can operate as a tool for questioning the way things are or seem to be. Over time it becomes a familiar place to inhabit. It offers both the comfort of familiarity and the promise of alterity simultaneously. This "storehouse of possibilities" is a space for imagination, reconfiguration and playful experimentation. As such, it offers the opportunity for a type of proxemic pedagogy, in other words a development that is based on the inhabitation of a certain type of psychical space that offers the potential for personal and collective expansion. As St John (2009a: 147) argues, rather than offering any kind of "passage" or "transit" to a postliminal state, many EDM events offer instead access to a "liminal culture" where tactical dramas may be enacted that are expositional, reclamational, and pedagogical in nature. 
Rather than functioning as a ritual stage of transition where initiands move from one social status to another, the liminal culture of psytrance offers an in-between space of permanent impermanence (St John 2010: 228) which one can revisit and inhabit at will as a diversion, a pastime or a socio-cultural tactic that might have "real world" applications.

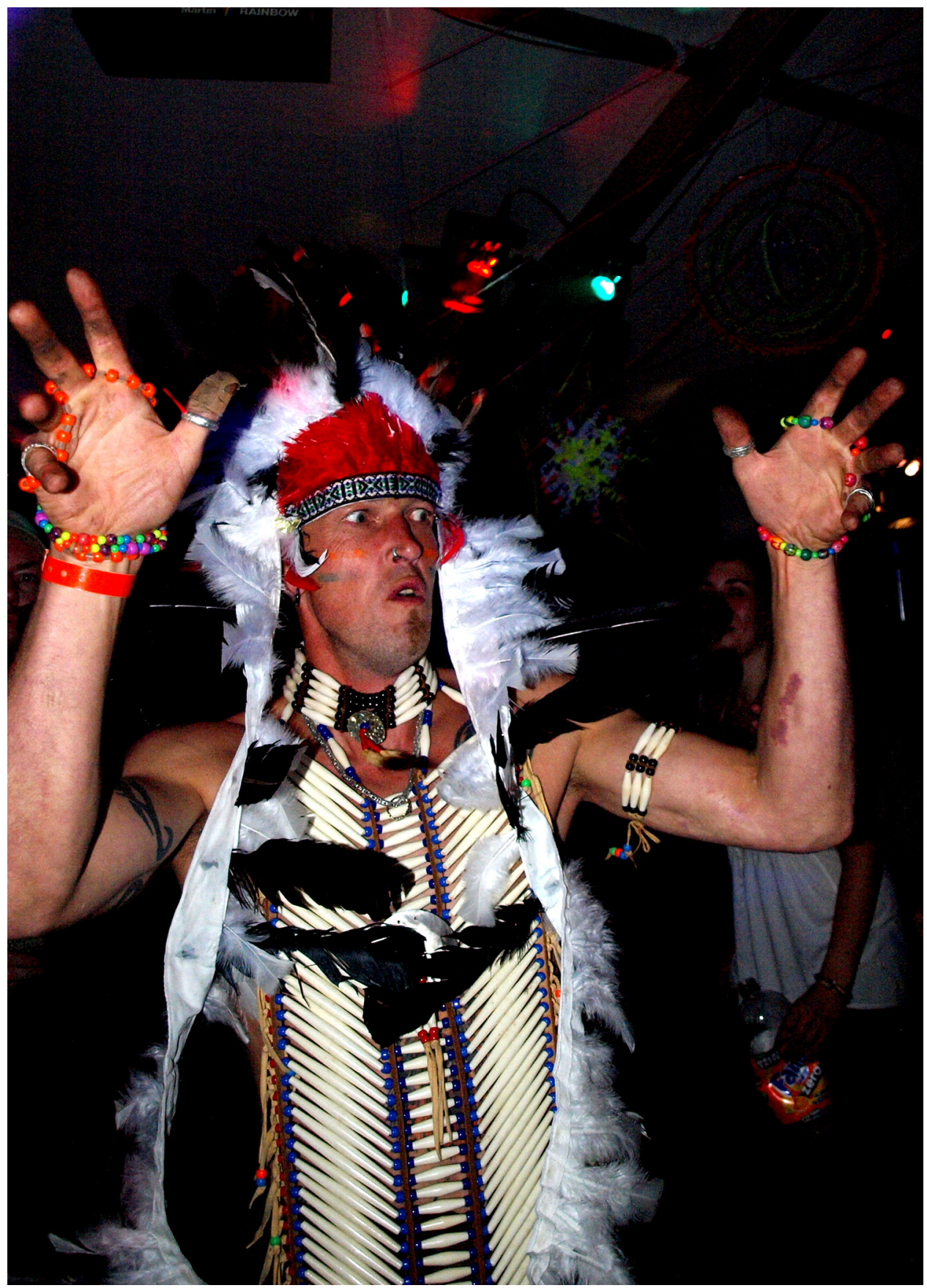

Figure 4. Costumed dancer at Shamania 2008. Photo: Ian M. Palmer. 


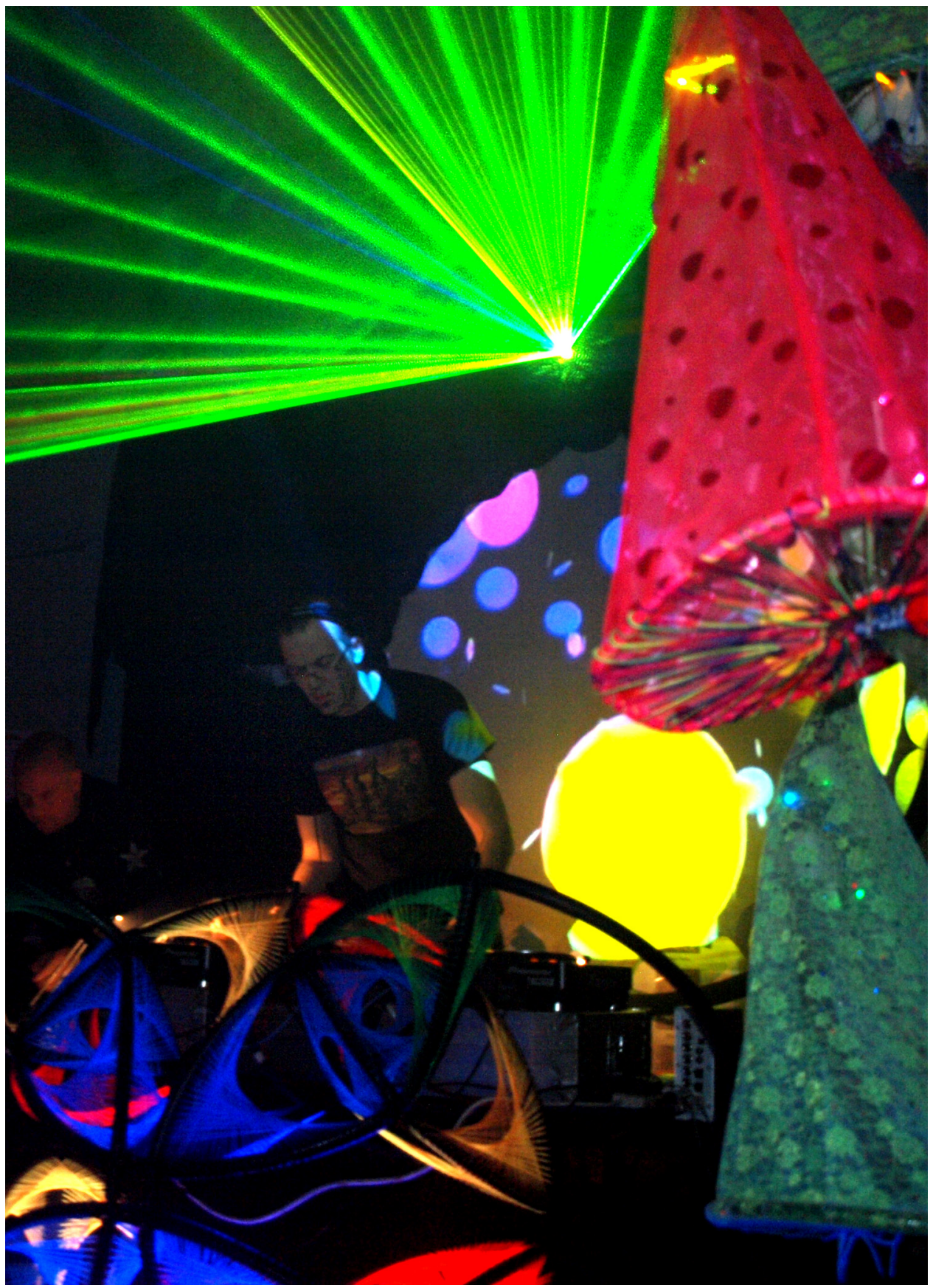

Figure 5. The psytrance dance floor at Sunrise, Leeds 2010. Photo: Ian M. Palmer.

The subjunctive mood of psytrance is expressed most visibly in terms of its aesthetic. Stemming from the Goan trance scene of the late 1980s and mutating over the past three decades, the liminal culture of psytrance has developed its own visual identity, largely borrowed from hippie psychedelia and Eastern mysticism, making its spaces of play instantly recognisable to fellow "psychonauts" across the globe. In performance studies discourse, 
Susan Broadhurst suggests that a key trait of liminality is the centrality of non-linguistic modes of signification such as the visual, the kinetic, the gravitational, the proxemic and the aural (1999: 12-13). At the psytrance party, environmental elements such as tranceinducing music, spatial organisation, elaborate UV decoration and disorienting light shows are clear examples of non-linguistic signification and add to the sense of "disruption, immediacy and excess" (Broadhurst 1999: 13) that is characteristic of the "core psytrance aesthetic" (Lindop 2009: 115) and of liminality itself. This is the scenography of the playful arena and provides the backdrop for the kind of embodied play participants may engage in. Psytrance parties and festivals are well known for their attention to detail, and considerable time and effort goes into decorating the physical environment as a means of emphasising "other-worldliness" and imagination."

As Davis suggests, the festival is "an incubator of novelty. A Petri dish of possibility where the future forms of community and consciousness are explored" (2008: 50). These spaces of play provide opportunities for individual and collective experimentation and give rise to the co-construction of new meaning, an activity that is normally the preserve of the artist. St John situates the psytrance festival as a "visionary arts festival" because of its heritage and structural affiliation to carnival and ceremony (2009b). For him, the psytrance festival "facilitates the performance of risk and discipline, accommodates the outlaw and the in-lore, is a stage for poetics and politics" (St John 2010: 242). As such, it occupies a significant cultural position in terms of its potential function for staging "dramaturgy of the margins" (Mullaney 1991: 22).

Collective protests of the early 1990s, such as the ones discussed earlier, placed marginal dramaturgy right in the heart of England's capital city and represented a close approximation of Hakim Bey's vision of the Temporary Autonomous Zone (TAZ), which seeks to move people beyond what he calls the "cartography of Control" (2003: 103). For van Veen (2002), the TAZ can be read as a pragmatic and psychotopological crack or liminal space, the likes of which have been investigated and made manifest by sound systems and art collectives such as Spiral Tribe, $\langle\mathrm{ST}\rangle$ and the KLF. It is in these liminal "cracks" that experimental performance occurs, not only within the underground context but in other domains where liminality sets in train a "blurring of set boundaries" (Broadhurst 1999: 13) and a questioning of "accepted ideas and belief systems" (Broadhurst 1999: 59). If we read the underground club space as providing the spatial and temporary frame for liminal cracks to be occupied, then it becomes a significant site of alterity, a possible "seedbed of cultural creativity" (Turner 1982: 28) where normative structures are suspended and experimentation can flourish. This seam of alterity and resistance has a rather more complex relationship with dominant discourse and social norms now that the lines between play and work, sacred and profane, virtual and real are less fixed and more open to (re)negotiation and mediation. The liminal space of the TAZ does not function as a clearly demarcated zone of transgression that returns people to regular, dominant social practices, as in the small-scale communities of Turner's original modelling. Relinquished from functioning solely as a "rite of passage" (see Van Gennep 1960), the liminal play space of the rave exists 
as an "elective place" (Hetherington 1998: 106) in which performative acts of imagination can be executed and new identities formed that then infuse and shape daily life. In other words, "the tribal carnival holds a unique intention-as the clearing house for a movement which seeks to export its liminality into the everyday" (St John 2009b: 51). Borrowing terminology from performance studies, this clearing house may also be conceived as a laboratory studio for the "rehearsal for reality" (Jackson in Boal 1992: xxi) where what has been felt, experienced and tried out in the safety of the play zone might inform and shape how we act and take action in the world of the everyday.

\section{CONCLUSION}

WHILST play is invoked in this article as a frame through which to view certain activities associated with underground club culture, my intention has been to draw together strands of common interest and concern across EDMC scholarship and performance studies in order to clarify the role of subjunctivity and the dynamic possibilities represented by play in this context. To this end I have suggested how play can be deployed to fulfil functionalist imperatives and how it can be mobilised for transgressive radicalism and provide a route towards expressivity that can be both individually and collectively embodied. The intention of this article has been to position the club space as a site of play and to highlight some of the dichotomies of that positioning. The dualities inherent in theorising about play are mirrored in the contradictions surrounding the clubbing experience. This article has not attempted to resolve those tensions, but instead brings into focus the multi-perspectival approach required when considering the club space as a potential seedbed where new models, symbols and paradigms may emerge (Turner 1982: 28).

The TAZ of the underground party is an "imaginal geography" (St John 2003: 74) that subscribes to a "horizontality of participation" (Gaillot 1999: 60). It offers a rhizomatic networked structure that promises access to a more creative world by basking "in multiplicities, lines of flight and becomings" (De Ledesma 2010: 90). As St John demonstrates, "as a contemporary site of belonging and identification, the dance club, party or festival is legion" (2009b: 40) and it is perhaps its "eventness" that lies at the heart of this and ties it so intimately to the world of play and performance where bodily copresence is paramount. The event is the locus of a play between identity and identification. As Hetherington suggests, these groupings and identity positions offer a distinct "structure of feeling" (1998: 16) where support, friendship, solidarity and community are established through the significance of "the occasion" (see Schmitt 1986). By providing a context for the performance of self and a presentation of persona that exceeds that of the routine self, individuals are given the license to embrace the "freaky self" (St John 2009b: 47) or, in my model, the "ludic self".

Where Gaillot positions the community of the techno-rave as a "laboratory of the present" (1999: 23-24) that offers a mode of being together that celebrates the sensation of "now-ness" (St John 2009a: 95), we might also understand it as a playground of the present. 
To experience play, or indeed "the vibe", fully, you cannot be located outside of it. You have to participate in it rather than observe it from a distance. The experience of it is located within the rhythmic body and is a result of the confluence of four core components-time, space, people and technologies. Constructing a space for pure play and maintaining the play state for prolonged periods might represent tactics of keeping the world of the everyday at bay, a childlike escape into the nowhere/nowhen land of utopia (Reynolds 1999). However, it might also be a reprioritisation and reclamation of the play state that mirrors a poetics of the threshold. Artists play in the limen in order to imagine alternative modes of being and doing, to make new meanings and to find expressive forms to articulate it. By playing collectively in the margins of meaning and by embracing liminal aesthetics as a lingua franca, participants recognise each other and find a communality that can transcend age, nationality and language. They find mutuality and play together as a rehearsal for reality. Not only do players learn about themselves, their own capacities and those of fellow players. By residing within the subjunctive mood, there also exists the potential to ask perhaps the most potent political question of all—"what if we did things differently?"

\section{ACKNOWLEDGEMENTS}

Many thanks to all the festival organisers, sound systems, DJs and party people who have engaged so generously with my research over the past five years and continue to do so. Thanks also to colleagues from the School of Performance and Cultural Industries for reading and commenting on earlier drafts of this work and to Ian M. Palmer of Madsnapper Photos for generously supplying images of Shamania 2008.

\section{NOTES}

1 For the purposes of this article, I will be referring to the broad category of "underground club culture". Whilst acknowledging the huge variations in what might be understood as 'underground', here I mean those events that are characterised predominantly by techno and psytrance music and that owe their heritage to the rave movement of the late 1980s and 1990s. Similarly, although I use the term "club" throughout the article, I use this term to denote events that may take place in outdoor locations as well as indoor venues. Indeed, much of my research refers to the context of the psytrance festival and to the free party scene that still exists in parts of the UK. The word "club" denotes the type of gathering rather than the physical architecture of a nightclub.

2 ...floorSpace... is an ensemble company created and developed by Alice O'Grady for the purposes of conducting practice-based research into interactive performance at festivals and underground clubs. Performers in the company were initially drawn from the undergraduate cohort at the University of Leeds and, after the initial period of research at Shamania, went on to perform and conduct research at other UK festivals including Kendal Calling, Nozstock, Magic Loungeabout and Beatherder.

3 Detailed description and analysis of the ...floorSpace... performances can be found in O'Grady (2009). 
4 Zorbing is a recreation activity where plastic, inflatable spheres that are big enough to hold people are rolled downhill on a gentle slope. Orbs are approximately three metres in diameter and can hold up to three people. They can also be used on a level surface, as was the case at Glade 2011.

5 Images of the Dance Off Saloon at Glade 2011 can be seen at < http://thedanceoffcrew.tumblr. $\underline{\mathrm{com} />}$ (goroboto 2010).

6 See McKay (1998) for a full discussion.

7 Footage of the Reclaim the Streets protest that took place in London in 1994 can be seen on "Spiral Tribe - Reclaim The Streets - 1994 UK CJB Protest" (2009). A Channel One news report on the 1994 road protest against the M11 link and the clearance of Claremont Road is available as "C1 Claremont Rd Pt1" (2009). Two reporters from Channel One, a local TV cable station for London, were the only broadcasters allowed to remain behind the defences of what had become known as "Leytonstonia" once the police had cleared all other journalists off the site before the arrival of the bailiffs. A comprehensive documentary detailing police intervention in the Exodus Collective's activities in the early 1990s can be seen at "Exodus from babylon part1" (2008).

8 PLUR stands for Peace Love Unity Respect and is an adage associated with the principles of the rave scene during the late 1980s and into the 1990s.

9 Sunrise, the UK's longest-running psytrance event that takes place at the West Indian Centre in Leeds, is noted for this aspect in particular. A recent review of Sunrise by Agnes Klos (2011) for Harderfaster features a description of the décor.

\section{REFERENCES}

Augé, Mark. 1995. Non-Places: Introduction to an Anthropology of Supermodernity. Trans. John Howe. London: Verso.

Austin, John L. 1963. How to Do Things with Words. Oxford: Clarendon Press.

Bahktin, Mikhail. 1998 [1968]. Rabelais and his World. Trans. Hélène Iswolsky. Cambridge, Mass.: MIT Press.

Bey, Hakim. 1994. Immediatism. Edinburgh: AK Press.

- - 2003 [1985]. TAZ: The Temporary Autonomous Zone-Ontological Anarchy, Poetic Terrorism. 2nd revised edition. New York: Autonomedia.

Boal, Augusto. 1992. Games for Actors and Non-Actors. Trans. Adrian Jackson. London and New York: Routledge.

Bourdieu, Pierre. 1979. La distinction: critique sociale de jugement. Paris: Minuit.

Broadhurst, Susan. 1999. Liminal Acts: A Critical Overview of Contemporary Performance and Theory. London: Cassell.

Buckland, Fiona. 2002. Impossible Dance: Club Culture and Queer World Making. Middletown, Conn.: Wesleyan University Press.

Caillois, Roger. 2001 [1958]. Man, Play and Games. Trans. Meyer Barash. Urbana and Chicago: University of Illinois Press.

Cohen-Cruz, Jan, and Mady Shutzman. 2006. A Boal Companion: Dialogues on Theatre and Cultural Politics. London and New York: Routledge. 
Dance-Off Crew, The. 2010. posted by goroboto. <http://thedanceoffcrew.tumblr.com/> (accessed 9 February 2012).

Davis, Erik. 2008. “The Festival is a Seed”. Pathways: Liminal Zine 2: 50-4.

De Ledesma, Charles. 2010. "Psychedelic Trance Music Making in the UK: Rhizomatic Craftsmanship and the Global Market Place”. In The Local Scenes and Global Culture of Psytrance, ed. Graham St John, 89-113. London and New York: Routledge.

Dolan, Jill. 2005. Utopia in Performance: Finding Hope at the Theatre. Ann Arbor: University of Michigan Press.

Fischer-Lichte, Erika. 2008 [2004]. The Transformative Power of Performance: A New Aesthetics. Trans. Saskya Jain. London and New York: Routledge.

Gaillot, Michel. 1999. Multiple Meaning Techno: An Artistic and Political Laboratory of the Present. Paris: Editions des Voir.

Gauthier, François. 2004. “Rapturous Ruptures: The 'Instituant' Religious Experience of Rave”. In Rave Culture and Religion, ed. Graham St John, 65-84. London and New York: Routledge.

- - . 2005. "Orpheus and the Underground: Raves and Implicit Religion-From Interpretation to Critique". Implicit Religion 8(3): 217-65.

Gardner, Howard. 1982. Art, Mind and Brain. New York: Basic Books.

Geertz, Clifford. 1973. The Interpretation of Cultures. New York: Basic Books.

Gerard, Morgan. 2004. "Selecting Ritual: DJs, Dancers and Liminality in Underground Dance Music". In Rave Culture and Religion, ed. Graham St John, 167-84. London and New York: Routledge.

Hetherington, Kevin. 1998. Expressions of Identity: Space, Performance, Politics. London: Sage.

Huizinga, Johan. 1949. Homo Ludens: A Study of the Play Element in Culture. London: Routledge and Kegan Paul.

Izzo, Gary. 1997. The Art of Play: The New Genre of Interactive Theatre. Portsmouth, N.H.: Heinemann.

Jackson, Phil. 2004. Inside Clubbing: Sensual Experiments in the Art of Being Human. Oxford: Berg.

Jordan, John. 1998. "The Art of Necessity: the Subversive Imagination of Anti-Road Protest and Reclaim the Streets". In DiY Culture: Party and Protest in Nineties Britain, ed. George McKay, 129-51, London: Verso.

Klos, Agnes. 2011. "Sunrise: the Longest Running Psytrance Night in the UK". HarderFaster. 20 July: <http://www.harderfaster.net/?section=features\&action=showfeature\&feature id=12338 > (accessed 9 February 2012).

Lindop, Robin. 2010. "Re-Evaluating Musical Genre in UK Psytrance". In The Local Scenes and Global Culture of Psytrance, ed. Graham St John, 114-30. London and New York: Routledge. Malbon, Ben. 1999. Clubbing: Dancing, Ecstasy and Vitality. London and New York: Routledge. McKay, George (ed.). 1998. DiY Culture: Party and Protest in Nineties Britain. London: Verso. McKenzie, Jon. 2001. Perform ... or Else: From Discipline to Performance. London and New York: Routledge. 
Moore, Cathi. 2011. “The Glade Festival 2011”. UK Festival Guides.

<http://www.ukfestivalguides.com/review/glade-2011-all-the-way-down-the-rabbit-hole> (accessed 19 January 2012).

Mullaney, Steven. 1991. "Civic Rites, City Sites: the Place of the Stage”. In Staging the Renaissance: Reinterpretations of Elizabethan and Jacobean Drama, ed. David Scott Kastan and Peter Stallybrass, 17-26. London and New York: Routledge.

Mumford, Meg. 2009. Bertolt Brecht. London and New York: Routledge.

Muñoz, Jose Esteban. 2006. "Queers, Punks and the Utopian Performative." In The Sage Handbook of Performance Studies, ed. D. Soyini Madison and Judith Hamera, 9-20. Thousand Oaks, Calif.: Sage.

O’Grady, Alice. 2009. “Underground Club Spaces and Interactive Performance”. Ph.D. thesis (Performance Studies), University of Leeds.

Olaveson, Tim. 2004. “'Connectedness' and the Rave Experience: Rave as New Religious Movement?" In Rave Culture and Religion, ed. Graham St John, 85-106. London and New York: Routledge.

Partridge, Christopher. 2006. “The Spiritual and the Revolutionary: Alternative Spirituality, British Free Festivals and the Emergence of Rave Culture". Culture and Religion 7(1): 41-60.

Piaget, Jean. 1951. Play, Dreams and Imitation in Childhood. Trans. C. Cattegno and F. M. Hodgson. London: W. Heinemann.

Reynolds, Simon. 1999. Generation Ecstasy: Into the World of Techno and Rave Culture. London and New York: Routledge.

Rill, Bryan. 2006. “Rave, Communitas, and Embodied Idealism”. Music Therapy Today 7(3): 648-61.

Schechner, Richard. 2006. Performance Studies. 2nd ed. London and New York: Routledge. Schmidt, Joshua I. 2009. “(En)Countering the Beat: Paradox in Israeli Psytrance”. In The Local Scenes and Global Culture of Psytrance, ed. Graham St John, 131-48. London and New York: Routledge.

Schmitt, Carl. 1986. Political Theology. Cambridge, Mass.: MIT Press.

St John, Graham. 2003. "Post-Rave Technotribalism and the Carnival of Protest". In The PostSubcultures Reader, ed. David Muggleton and Rupert Weinzierl, 65-82. London: Berg.

_- _. 2004. “The Difference Engine: Liberation and the Rave Imaginary”. In Rave Culture and Religion, ed. Graham St John, 19-45. London: Routledge.

-—_. 2009a. Technomad: Global Raving Countercultures. London: Equinox.

_- _ 2009b. "Neotrance and the Psychedelic Festival". Dancecult: Journal of Electronic Dance Music Culture 1(1): 35-64.

$<$ http://dx.doi.org/10.12801/1947-5403.2009.01.01.03 > (accessed 23 November 2011).

- _ . 2010. "Liminal Culture and Global Movement: The Transitional World of Psytrance". In The Local Scenes and Global Culture of Psytrance, ed. Graham St John, 220-46. London and New York: Routledge.

Sutton-Smith, Brian. 1999. "Evolving a Consilience of Play Definitions: Playfully". In Play and Culture Studies, ed. Stuart Reifel, vol. 2, Play Contexts Revisited. 239-256. Stamford, Conn.: Ablex. 
Sylvan, Robin. 2005. Trance Formation: The Spiritual and Religious Dimensions of Global Rave Culture. London and New York: Routledge.

Tramacchi, Des. 2000. "Field Tripping: Psychedelic Communitas and Ritual in the Australian Bush". Journal of Contemporary Religion 15(2): 201-13.

Turner, Victor. 1982. From Ritual to Theatre: the Human Seriousness of Play. New York: Performing Arts Journal Publications.

- — . 1983. "Body, Brain and Culture". Zygon 18(3): 221-45.

Turner, Victor and Edward Bruner (ed.). 1986. The Anthropology of Experience. Urbana and Chicago: University of Illinois Press.

Van Gennep, Arnold. 1960 [1909]. The Rites of Passage. London: Routledge and Kegan.

van Veen, Tobias c. 2002. "It's Not A Rave, Officer, It's Performance Art: Art as Defense from the Law and as Offense to Society in the Break-In Era of Rave Culture". University Art Association of Canada Conference. <http://www.quadrantcrossing.org/papers/It's Not A Rave-UAACtV.pdf> (accessed 23 November 2011).

Vygotsky, Lev Semenovich. 1978. Mind in Society: the Development of Higher Psychological Processes. Cambridge, Mass.: Harvard University Press.

Winnicot

\section{FILMOGRAPHY}

"C1 Claremont Rd Pt1". 2009. YouTube. <http://www.youtube.com/watch?v=stDKsHyhVeM> (accessed 9 February 2012).

"Exodus from babylon part1". 2008. YouTube < http://www.youtube.com/watch?v=r0WeW3r48A $>$ (accessed 9 February 2012).

"Spiral Tribe - Reclaim The Streets - 1994 UK CJB Protest". 2009. YouTube, 3:38. < http://www. youtube.com/watch?v=PEYtMBI1IeU> (accessed 9 February 2012). 